\title{
A Study on Financial Performance of Ashok Leyland Limited at
} Chennai.

\author{
${ }^{1 .}$ R.Idhayajothi, ${ }^{2}$ Dr.O.T.V.Latasri, ${ }^{3 .}$ N. Manjula, ${ }^{4}$ A.Meharaj Banu, \\ ${ }^{5}$ R. Malini \\ 1.Assistant Professor, Centre for Research-Department of Commerce, Srimad Andavan Arts \& Science College, \\ T.V. Koil, Trichy- 5 \\ 2. Head-PG, Centre for Research-Department of Commerce, Srimad Andavan Arts \& Science College, T.V. \\ Koil, Trichy- 5 \\ 3. Assistant Professor, Centre for Research-Department of Commerce, Poompuhar College, Melaiyur, Nagai \\ District. \\ 4. Assistant Professor, Centre for Research-Department of Commerce, Srimad Andavan Arts \& Science \\ College, T.V. Koil, Trichy- 5 \\ 5. Assistant Professor, Centre for Research-Department of Commerce, Srimad Andavan Arts \& Science \\ College, T.V. Koil, Trichy- 5
}

\begin{abstract}
Financial is regarded as the life blood of a business enterprise. In the modern oriented economy, finance is one of the basic foundations of all kinds of economics activities. Finance statements are prepared primary for decision -making. They play a dominant role in setting the frame work and managerial conclusion and can be drawn from these statements is of immense use in decision-making through analysis and interpretation of financial statements. As said earlier finance is said to be life blood of any business Every business under taking needs finance for its smooth working it has to raise funds from the cheapest and risky source to utilize this in most effective manner. So every company will be interested in knowing its financial performance.The project entitled "Financial performance analysis of Ashok Leyland company Ltd" throw light on overall financial performance of the company.
\end{abstract}

Keywords: The term ratio is refers to the relationship expressed in mathematical terms between two individual figures. procedures.

A financial statements is an organized collection of data according to logical and consist ant accounting

The income statements give the total of different expenditure and revenues during the given period and the net result, viz., profit or loss during the given period. The balance sheet shows the balance of assets, liabilities and the capital as on the last date of the accounting period .changes in these items between two dates and the effect of such changes. For this purpose, different tools of analysis are used by managements. Such analysis of items in the financial statements by using different tools of analysis is called financial statements analysis.

A financial statement is an organized collection of data according to logical and consist ant accounting procedures. Its purpose is to convey an outstanding of some financial aspects of a business firm. It may show a position at a moment of time as in the case of balance sheet, or may reveal a series of activities over a given period of time, as in the case of an income statement.

\section{Definition:}

According to Metcalf and Titard,"Analysis financial statements is a process of evaluating the relationship between component parts of financial statements to obtain a better understanding of firm's position and performance"

\section{Financial statement}

A financial statement is an organized collection of data according to logical and consistent accounting procedures. Its purpose is to is to convey an understanding of some financial aspects of a business firm. It may show a position at a moment of time as in the case of a balance sheet, or may reveal a activities over a given Period of time, as in the case of an income statement.

Thus, the term financial statement generally refers to the basis statements:

1) The income statement, 2) The balance sheet, 3) A statement of retained earnings,

4) A statement of charge in financial position in addition to the above two statement. 


\section{Financial statement Analysis:}

It is the process of identifying the financial strength and weakness of a firm from the available accounting data and financial statement. The analysis is done by properly establishing the relationship between the items of balance sheet and profit and loss account the first take of financial analyst is to determine the information relevant to the decision under consideration form the total information contained in the financial statement. The second step is to arrange information in a way to highlight significant relationship. The final step is interpretation and drawing of inferences and conclusion. Thus financial analysis is the process of selection relating and evaluation of the accounting data information.

This studying contain following analysis:

$\checkmark \quad$ Ratio analysis, Liquid ratios, solvency ratios.

\section{Ratio Analysis:}

Ratio analysis is a widely used tool of financial analysis. The term ratio is refers to the relationship expressed in mathematical terms between two individual figures or group of figures connected with each other in some logical manner and are selected from financial statements of the concern. It helps to express the relationship between two accounting figures in such a way that users can draw conclusions about the performance, strengths and weakness of a firm.

\section{Scope Of The Study:}

1. The study covers the financial performance of the Ashok Leyland.

2. The study is made by making comparison of five year of it operation.

3 . The study covered aims to reveal where the stands in respect to liquidity and an

effective use of asset.

\section{Objectives Of The Study:}

1. To know the financial position of the Ashok Leyland.

2. To know the Liquidity and profitability position of the company.

3. To know the financial strength and weakness of the company.

\section{Research design:}

\section{Research Methodology}

The study is based on secondary data. Data pertaining behaviour of liquidity solvency and profitability position were collection from the balance sheet and profit \& loss account of Ashok Leyland. The necessary data were obtained from published annual report.

\section{Nature of data:}

The data required for the study has been collected from secondary sources and the relevant information were taken from annual reports, journals and internet etc.,

\section{Tools applied:}

To have a meaningful analysis and interpretation of various data collected, the following tools were made for this study.

$>\quad$ Ratio analysis ,Common -size statement, Comparative statement, Trend analysis

\section{Literature Review}

Gary W.selnow(2003) examined various approaches to promote retirement investment .His study found that automatic enrolment has a good chance of overcoming the natural impediments to wise decisions about retirement investments.

Douglas A.Hersahey and Hendrik p. Van Dalen(2006)in the study explored the Psychological mechanisms that underlie the retirement planning and saving tendencies of Dutch and American Workers the research suggests that policy analysts should take into account both individual and cultural differences in the psychological predispositions of workers when considering Pension reforms that stress individual responsibility for planning and saving.

M.Kabir Hassan and Dr.Shari Lawrance (2007) conducted a survey on "An Analysis of Financial preparation for Retirement ". In this study, the researcher analyzes the financial preparation for retirement. Regarding retirement plan contributions, the findings indicate significant positive effects regarding income and womanhood .Education is significant and positive as a predictor for the decision to contribute to a pension plan for women in their their thirties, Thus supporting the hypothesis of a significant positive relationship between education and pension plan Contributions. 


\section{Classification of ratios}

a) Liquidity ratios, Leverage ratios, Activity ratios, Profitability ratio

\section{Liquidity Ratio:}

These ratios portray the capacity of the business unit to meet its short term obligation from its shortterm resources (e.g.) current ratio, quick ratio.

\section{Current Ratio:}

Current ratio may be defined as the relationship between current assets and current liabilities it is the most common ratio for measuring liquidity. It is calculated by dividing current assets and current liabilities. Current assets are those, which can be realized with in a period of one year. Current liabilities are those amounts, which are payable with in a period of one year.

\section{Current Ratio $=\quad$ current Assets $/$ Current liabilities}

Current Assets Ratio

\begin{tabular}{|l|l|l|l|}
\hline YEAR & CURRENT ASSETS & CURRENT LIABILITIES & RATIO \\
\hline $\mathbf{2 0 0 8 - 2 0 0 9}$ & 374.91 & 2207.29 & 1.08 \\
\hline $\mathbf{2 0 0 9 - 2 0 1 0}$ & 2849.22 & 3002.68 & 0.95 \\
\hline $\mathbf{2 0 1 0 - 2 0 1 1}$ & 3573.64 & 3505.26 & 1.02 \\
\hline $\mathbf{2 0 1 1 - 2 0 1 2}$ & 3493.56 & 4837.41 & 0.72 \\
\hline $\mathbf{2 0 1 2 - 2 0 1 3}$ & 3329.37 & 4749.58 & 0.70 \\
\hline
\end{tabular}

\section{Source: secondary data}

\section{Interpretation:}

The above table and diagram shows that the current ratio in the year 2008-09 was 1.08 and then it decreases to 0.95 in the year 2009-10, next year onwards it move upwards to 1.02 in the year 2010-11 and it again moves down to 0.72 and finally in the year 2012-13 it again moved down to 0.70 Profitability ratios The normal current ratio is $2: 1$. The above table shows current ratio is less than $2 \%$ in all the financial years. This shows that the company is not enjoying credit worthiness.

\section{Liquidity Ratio:}

The term 'liquidity' refers to the ability of a firm to pay its short-term obligation and when they become due. The term quick assets or liquid assets refers current assets which can be converted into cash immediately and it comprises all current assets except stock and prepaid expenses it is determined by dividing quick assets by quick liabilities.

\section{Liquidity ratio $=\quad$ Liquid assets/ Liquid liabilities}

Source:

\section{Liquidity Ratio}

\begin{tabular}{|l|l|l|l|}
\hline Years & Liquid assets & Liquid liabilities & Ratio \\
\hline $2008-2009$ & 1308.46 & 2207.29 & 0.59 \\
\hline $2009-2010$ & 1537.13 & 3002.68 & 0.51 \\
\hline $2010-2011$ & 2594.74 & 3505.26 & 0.74 \\
\hline $2011-2012$ & 2797.41 & 4837.41 & 0.58 \\
\hline $2012-2013$ & 3770.98 & 4749.58 & 0.79 \\
\hline
\end{tabular}

\section{Secondary Data}

\section{Interpretation:}

The above table and diagram shows that the liquidity ratio during the study period is lower than the normal (i.e.) 1:1.It was 0.59 in the year 2008-09 and further reduced to 0.51 in 2009-10 and it has been fluctuating and are below the normal ratio. Hence the firm is not controlling its stock position because there are linear relationship between current ratio and liquidity ratio

\section{Absolute Liquidity Ratio:}

Absolute liquidity ratio includes cash, bank, and marketable securities. This ratio obtained by dividing cash, bank and marketable securities by current liabilities. 


\section{Absolute liquidity ratio $=$ Cash + bank + marketable securities/ Current liabilities}

Absolute Liquidity Ratio

\begin{tabular}{|l|l|l|l|}
\hline Years & Cash and securities & Current liabilities & Ratio \\
\hline $2008-2009$ & 350.49 & 2207.29 & 0.16 \\
\hline $2009-2010$ & 515.07 & 3002.68 & 0.17 \\
\hline $2010-2011$ & 1409.53 & 3505.26 & 0.40 \\
\hline $2011-2012$ & 1567.04 & 4837.41 & 0.32 \\
\hline $2012-2013$ & 2351.57 & 4749.58 & 0.50 \\
\hline
\end{tabular}

\section{Source: Secondary Data}

\section{Interpretation}

The above table and diagram shows the absolute ratio for the study period 2008-09 to 2012-13. There is a fluctuation in the absolute ratio.It was 0.16 in the year 2008-09. In 2009-10 it is 0.17 and 2010-11 it was 0.40 . It was 0.32 in 2011-12 and it increases to 0.50 in the year 2012-13

\section{Leverage Ratio:}

Many financial analyses are interested in the relative use of debt and equity in the firm. The term 'solvency' refers to the ability of a concern to meet its long-term obligation. According to, long-term solvency ratios indicate a firm's ability to meet the fixed interests, costs and repayment schedules associated with its long-term borrowings. (E.g.) debt equity ratio, proprietary ratio, etc....

\section{Debt Equity Ratio :}

expresses the relationship between the external equities and internal equities or the relationship between borrowed funds and 'owners' capital. It is a popular measure of the long-term financial solvency of a firm. This relationship is shown by the debt equity ratio. This ratio indicates the relative proportion of debt and equity in financing the assets of a firm. This ratio is computed by dividing the total debt of the firm by its equity (i.e.) net worth.

\section{Debt equity ratio $=\quad$ Outsider's funds $/$ Proprietor's funds}

\section{Debt Equity Ratio}

\begin{tabular}{|l|l|l|l|}
\hline Years & Outsider's funds & Proprietor's funds & Ratio \\
\hline $2008-2009$ & 1961.98 & 133.03 & 14.75 \\
\hline $2009-2010$ & 2280.45 & 133.03 & 17.14 \\
\hline $2010-2011$ & 2658.19 & 133.03 & 19.98 \\
\hline $2011-2012$ & 2395.53 & 266.07 & 9.00 \\
\hline $2012-2013$ & 3504.82 & 266.07 & 13.17 \\
\hline
\end{tabular}

\section{Source: Secondary Data}

\section{Interpretation:}

The above table and diagram shows that the debt equity relationship of the company during the study period. It was 14.75 in the year 2008-09 and then reached up to 17.14 again in the next year moved up to 19.98 but from the year 2011-12 onwards it ultimately come down to .00 and in the year 2012-13 it again moved up to 13.17. In all the years the equity is less when compared with borrowings. Hence the company is not maintaining its debt position

\section{Proprietory Ratio:}

Proprietary ratio relates to the proprietors funds to total assets. It reveals the owners contribution to the total value of assets. This ratio shows the long-time solvency of the business. It is calculated by dividing proprietor's funds by the total tangible assets.

Proprietary ratio $=$ Proprietor's funds $/$ Total tangible assets. 
Proprietary Ratio

\begin{tabular}{|l|l|l|l|}
\hline Years & Proprietor's funds & Total assets & Ratio \\
\hline $2008-2009$ & 133.03 & 5435.87 & 0.02 \\
\hline $2009-2010$ & 133.03 & 5936.76 & 0.02 \\
\hline $2010-2011$ & 133.03 & 6621.14 & 0.02 \\
\hline $2011-2012$ & 266.07 & 6607.32 & 0.04 \\
\hline $2012-2013$ & 266.07 & 7959.92 & 0.03 \\
\hline
\end{tabular}

\section{Source :Secondary data}

\section{Interpretation :}

The above table and diagram shows that the proprietary ratio during the study period. In all the years the owner's contribution to the total assets was appropriate and they maintain their share in the company's assets.

\section{Activity Ratio:}

These ratios evaluate the use of the total resources of the business concern along with the use of the components of total assets. They are intended to measure the effectiveness of the assets management the efficiency with which the assets are used would be reflected in the speed and rapidity with which the assets are converted into sales. The greater the rate of turnover, the more efficient the management would be the stock turnover ratio, fixed assets turnover ratios etc....

\section{Total Assets Turnover Ratio :}

This ratio is an indicator of how the resources of the organization utilized for increasing the turnover. It shows the ratio between the total assets and the net sales of the company.From this ratio one can understand how the assets are performing and being utilized in achieving the objectives of the company.

\section{Total assets turnover ratio $=$ Total assets $/$ Net assets}

\section{Ratio On Total Assets:}

Profitability can be measured in terms of relationship between net profit and total assets. It measures the profitability of investment. The overall profitability can be known by applying this ratio

\section{Return on total assets $=$ Net profit/ Total assets $\mathbf{x 1 0 0}$}

\section{Profitability Ratio:}

The profitability ratios of a business concern can be measured by the profitability ratios. These ratios highlight the end result of business activities by which alone the overall efficiency of a business unit can be judged. (E.g.) gross Profit ratios, Net profit ratios.

\section{Gross Profit Ratio :}

This ratio expresses the relationship between Gross profit and sales. It indicated the efficiency of production or trading operation. A high gross profit ratio is a good management as it implies that the cost of production is relatively low.

\section{Gross profit ratio $=$ Gross profit $/$ Net sales $\times 100$}

\section{GROSS PROFIT RATIO}

\begin{tabular}{|l|l|l|l|l|}
\hline Years & Gross profit & Net sales & $\mathbf{1 0 0}$ & Ratio \\
\hline $2008-2009$ & 473.09 & 6168.99 & 100 & 7.67 \\
\hline $2009-2010$ & 761.40 & 7436.18 & 100 & 10.24 \\
\hline $2010-2011$ & 1217.56 & 11407.15 & 100 & 10.67 \\
\hline $2011-2012$ & 1256.35 & 13309.59 & 100 & 9.44 \\
\hline $2012-2013$ & 12488.58 & 100 & 7.02 \\
\hline
\end{tabular}

\section{Source: Secondary Data Interpretation:}

The above table and diagram shows the relationship between the gross profit and net sales in percentage. During the study period the average gross profit position was $9 \%$ and it is in decreasing trend, however the company maintains a good gross profit ratio 


\section{Net Profit Ratio :}

Net profit ratio establishes a relationship between net profit (after taxes) and sales. It is determined by dividing the net income after tax to the net sales for the period and measures the profit per rupee of sales

Net profit Ratio $=$ Net profit $/$ Net sales $\times 100$

\section{Findings:}

\section{Findings, Suggestions And Conclusions}

* The current ratio in the year 2008-09 was 1.08 and then it decreases to 0.95 in the year 2009-10, next year onwards it move upwards to 1.02 in the year 2010-11 and it again moves down to 0.72 and finally in the year 2012-13 it again moved down to 0.70 . The normal current ratio is $2: 1$. The above table shows current ratio is less than $2 \%$ in all the financial years. This shows that the company is not enjoying credit worthiness.

* The liquidity ratio during the study period is lower than the normal (i.e.) 1:1.It was 0.59 in the year 200809 and further reduced to 0.51 in 2009-10 and it has been downward trend. Hence the firm is not controlling its stock position because there are linear relationship between current ratio and liquidity ratio.

* There is a fluctuation in the absolute Ratio It was 0.16 in the year 2008-09. In 2009-10 it is 0.17 and 2010-11 it was 0.40. It was 0.32 in 2011-12 and it increases to 0.50 in the year 2012-13.

* The debt equity relationship of the company during the study period was 14.75 in the year 2008-09 and then reached up to 17.14 again in the next year moved up to 19.98 but from the year 2011-12 onwards it ultimately come down to 9.00 and in the year 2012-13 it again moved up to 13.17. In all the years the equity is less when compared with borrowings. Hence the company is not maintaining its debt position.

* The net profit and net sales during 2008-09 it was 3.08\% on sales and in 2009-10 it was 5.70\%. But in all other 3 years it is moved downwards. This means that there is a defect in pricing the product or excess non-value added expenditures which reduces the net profit of the company. The sales are increasing; hence the management should take care of the quality and market situations. The administration and selling expenses are normal.

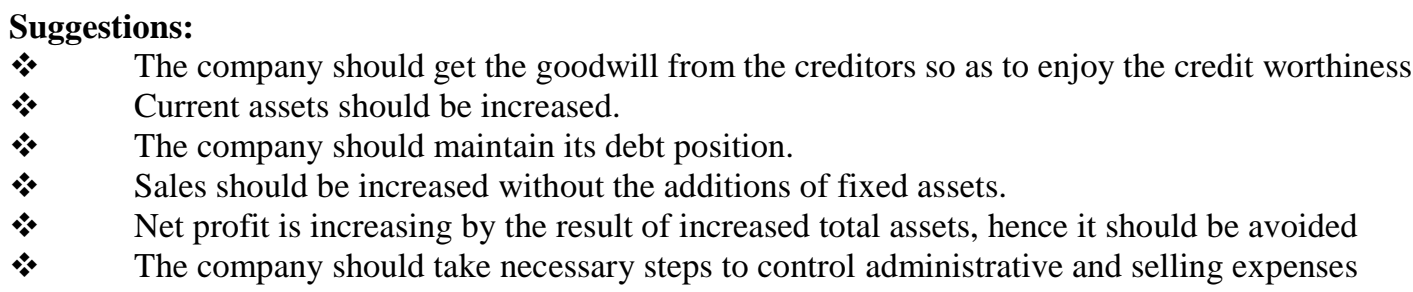

\section{Conclusion:}

The study reveals that the financial performance is fair. It has been maintaining good financial performance and further it can improve if the company concentrates on its operating, Administrative and selling expenses and by reducing expenses. The company should increase sales volume as well as gross profit. Despite price drops in various products, the company has been able to maintain and grow its market share to make strong margins in market, contributing to the strong financial position of the company. The company was able to meet its entire requirements for capital expenditures and higher level of working capital commitment with higher volume of operations and from its operating cash flows.

\section{Books:}

\section{Bibliography}

[1]. Management Accounting- R.Ramachandran \& R.Srinivasan - Sriram Publications, Trichy.

[2]. Management Accounting -Dr. M. Sheik Mohaned, Dr. E.Mubarak Ali, Dr. M.Abdul Halleem -Raja publications - Reprint 2012.

[3]. Management Accounting - R.S.N. Pillai, Bagavathi -S. Chand \& company Ltd December 2005.

[4]. Research Methodology - P. Saravanavel - Kitabmahal Allahabad.

[5]. Research Methodology - G.R. Kothari -Second Edition Jaipur -May 1990. Financial Management -Sawalia Bihari verma - Asian Books privaid ltd 2010.

[6]. Financial Management - C. Paramasivan, T. Subramanaian - New age international Publishers2009.

[7]. Advanced Management Accounting - Prof. Jawahar Lal - S.Chand \& Company Ltd - New Delhi.

[8]. Management Accounting - V.K. Saxena, C.D. Vashist - Surtan Chand \& Sons - New Delhi.

[9]. Management Accounting - TS. Reddy, Y. Hari Prasad, Reddy - Margham Publications Chennai.

\section{Journal :}

[10]. Indian Journal of finance -Dr Ashok Khurana - November 2009.

[11]. International journal of Business\& Social Science Vol.3 NO.14 (Special issue Jully 2012).

[12]. Indian Journal of Finance - Sreesha C.H. Dr. M.A.Josph - Jully 2011. 
Wedsites :

[13]. http:// www.money control .com

[14]. http:// www.google.com.

[15]. http:// www.indian overseas bank.com

[16]. http:// www.yahoo.com

[17]. http:// www. Ask.com 